\title{
Application of the New Moroccan Family Code in Spain (with a Gender Perspective)
}

\author{
Gloria Esteban de la Rosa \\ Public and Private Law Department, University of Jaén, Jaén, Spain \\ Email: gesteban@ujaen.es
}

Received January $14^{\text {th }}, 2013$; revised February $22^{\text {nd }}, 2013$; accepted March $18^{\text {th }}, 2013$

\begin{abstract}
Copyright (C) 2013 Gloria Esteban De La Rosa. This is an open access article distributed under the Creative Commons Attribution License, which permits unrestricted use, distribution, and reproduction in any medium, provided the original work is properly cited.
\end{abstract}

\begin{abstract}
The application of the Moroccan Family Code by Spanish legal operators is not simple, to the extent that it is not only a question of knowing its contents, but also, behind each of its articles and, relating to the institutions contained in the Code, there is a specific understanding of the world and, more specifically, family relations. The Spanish system of Private International Law is to serve as a "communication channel" between legislations which are beginning to coincide due to the new private international situations taking place in Spain, as a new foreign population begins to settle, in particular when it comes to female Moroccan immigrants. In these cases, Moroccan family law may be applied or considered by the Spanish authorities, favouring thus the recognition of decisions taken in Morocco.
\end{abstract}

Keywords: Moroccan Family Law; Implementation of the New Moudawana in Spain; Dowry; Mut'a; Dissolution of Marriage by Talaq and Tatliq; Revocable Dissolution; Public Policy

\section{Introduction}

The Moroccan Family Code (FC) which came into play on 5th February 2004 repealed the Code of Personal Status and Inheritance (1957-58), better known as the old Moudawana (summary). On 23rd January the Moroccan Parliament unanimously approved the new Code. On 5th February 2004 this was published in the Official Gazette of Morocco (No. 5184). For a better understanding of this new text overseas, the Ministry of Justice has prepared a French translation, which is accompanied by a commentary on each of its provisions, in order to guide the user in the direction of reform.

The current FC is made up of 400 articles, which regulates in six Books: Marriage (Book 1), the dissolution of the bonds of matrimony and its effects (Book 2), Birth and its effects (Book 3), Legal capacity and representation (Book 4), Wills (Book 5), Inheritance (Book 6). Book 7 contains a collection of interim and final provisions.

The FC is based on tolerant Islam which honours man and preaches justice. As highlighted by the King of Morocco on the occasion of the opening of the autumn parliamentary session of 2003, the FC should be interpreted as a policy aimed at the entire family, which serves several purposes: to overcome the inequality that weighs upon women, to protect the rights of children and to preserve the rights of man. The Sovereign tried to reconcile in this way, the development requirements of the country whilst ensuring family rights were upheld. This new legal instrument is both linked to the precepts of Islam and the rules of universally recognized Human Rights.

In this way the FC is based on the principles of Islam as an egalitarian and tolerant religion, given that, despite the views of other more radical legal schools, Islam can be a source of modernity. There is, however, still debate over ijtihad, between those who consider the interpretation to be dangerous and those who are in favour of it.

This has gradually become a formal debate, given that the interpretation is considered to be not only necessary but, to all intents and purposes, indispensable, as, of the 80 verses contained in the Koran dealing with the rules of Law, many are not applicable in our times as the historical context for which they were written no longer exists.

For this reason, the Monarch of Morocco issued a FC, with the conviction that Islam gives women a number of rights, to be regulated and exercised by them. Thus, the Code advocates ijtihad, which, as seen above, is the interpretation of the Koran in the context of modern society and its demands, contrary to patriarchal hierarchy and designed to validate arguments present in sacred legal texts.

Like other Muslim countries, Morocco applied classical Muslim law, which led to the birth of various rites or schools (see below for more detail). On issues of personal status, Morocco followed the malikí doctrine up until the enactment of the Personal Status and Inheritance Code (previously Moudawana). In this sense, 400 articles of the current FC stated that, for all issues not addressed by a text in the present Code, reference may be made to the Malikite School of Jurisprudence and to ijtihad (juridical reasoning). This came about in response to the need for a norm to regulate family relations in accordance with the precepts of the Koran, above all to end “Urf' Law (on local customs and practices).

The Moudawana responded to this purpose, but furthermore it captured the situation of discrimination lived by women throughout the 1950s. Although there had been previous specific reforms (1993), family law underwent a significant change with the entry into force in February 2004 of the FC, which repealed the Moudawana. Women's associations had been 
calling for this reform for decades. King Mohammed IV made a speech to parliament on 10th October 2003 in which he outlined his intention to preserve the principles of Islamic legislation whilst considering the social evolution undergone by Moroccan society.

The Code contributes to the construction of an open, progressive, democratic society, based on the protection of women's rights. As stated in the Doctrine, in the Maghreb, both family and society are undergoing a double evolution: firstly, man no longer dominates woman, except in legal issues, and a father no longer dominates his children (Fargues, 1996).

\section{The Moroccan Family Code of 2004: Main Modifications}

The FC clarifies the concept of head of family, in that it considers the sharing of responsibility between the two spouses a necessary condition for the construction of a family, and underlines the importance of mutual comprehension and consent in managing all issues relating to the family. Article 4 FC states that: "Marriage is a legal contract by which a man and a woman mutually consent to unite in a common and enduring conjugal life. Its purpose is fidelity, virtue and the creation of a stable family, under the supervision of both spouses according to the provisions of this Moudawana".

It also annuls the wilaya, so that a woman can enter into matrimony without the consent of a legal representative. Article 25 of the FC states that: "The woman of legal majority may conclude her marriage contract herself or delegate this power to her father or one of her relatives". A dowry must be presented (according to article 26 FC). However article 13 of the FC, on the requirements of marriage, refers specifically to there being "no intention or agreement to cancel the dowry". Finally, the aspect of the regulation of marriage which causes greatest controversy in the eyes of Western legal systems is the requirement that a woman marries a Muslim.

Although polygamy is upheld, some limitations have been introduced, so that a man needs court approval to marry for a second or successive time. Repudiation and polygamy have been well received in Arab countries as a result of a surplus of women in the marriage market. However, this is not a natural excess, but is rather the product of a society, the arithmetic result of a rule (the universality of marriage) and a custom (the big age difference between spouses), which have led to a patriarchal model of the family. Polygamy is nevertheless quite rare in contemporary Maghreb. A judge will not give authorization until he is certain that it is fair to the wives.

Article 40 of the FC states that: "Polygamy is forbidden when there is the risk of inequity between the wives. It is also forbidden when the wife stipulates in the marriage contract that her husband will not take another wife". The woman can also introduce as a condition in the marriage contract that, if her spouse marries again, she has the right to file for divorce.

The FC has also simplified the procedure to be followed by Moroccan Muslims who wish to enter into marriage overseas. They can celebrate the marriage according to the local administrative procedures of their country of residence, provided that the conditions of consent (offer and acceptance), capacity and offering of the dowry are fulfilled, and the ceremony is held in the presence of at least two Muslim witnesses. A copy of the marriage contract must be submitted within three months of its conclusion to the Moroccan consular section (articles 14, 15 FC).
The celebration of marriage is said to be valid if the parties are in agreement, expressed through offer and acceptance. Moroccan case law prior to the entry into force of the new FC tried to relax and facilitate the marriage of Moroccans abroad. The sentence of the Supreme Court (no. 835) of 19th June 1990 (Dossier of the Supreme Court 86/8331) considered a marriage celebrated in a non-Muslim country to be valid, even though the adouls (public notaries) were not present when the marriage was celebrated. The claimant's situation was exceptional, given that he brought together 12 people who were present at the act of celebration of the marriage and the party which followed, who were able to act as witnesses.

Regarding the dissolution of marriage, this can occur through ta'liq or talaq, as well as through death of either spouse, (or the issuance of a judgement declaring him or her deceased when there is uncertainty surrounding the fact), through the existence of a defect (noted at the time of celebrating the marriage), or other causes stipulated in the Code (article 71). Finally, another relevant provision is article 128 of the FC, which allows recognition in Morocco of decisions rendered by foreign courts concerning divorce through tatliq or talaq, through mutual consent or annulment, as long they are issued by a court with jurisdiction over the matter and are based on grounds for terminating the marriage relationship that do not contradict those contained in this Moudawana.

In any case, the conditions and procedures laid out in articles 430 - 432 of the Code of Civil Procedure must be met. Approved by Dahir, 28th September 1974 (Official Gazette of Morocco 30th September). These provisions constituted a significant step for the modernization of Moroccan private international law, together with the reform of the legal system by Dahir on the 26th January 1965 (Official Gazette of Morocco 3rd February 1965), which eliminated the duality of jurisdictions present until this time. This new regulation incorporates the jurisprudence of the Supreme Court of Morocco in the approval of decisions taken overseas.

\section{Difficulties in Applying the New Moudawana}

The application of the FC by Spanish legal operators is not simple, to the extent that it is not only a question of knowing its contents, but also, behind each of its articles and, relating to the institutions contained in the Code, there is a specific understanding of the world and, more specifically, family relations.

Furthermore, the provisions present in the FC cannot be read disregarding the fact that Islam is the official State religion in Morocco, recognised as such under the constitution, on the one hand and, on the other, that the Code is the part of positive Moroccan Law most highly influenced by Islamic Law, given that following Independence many of the Codes adopted during foreign domination (French Protectorate) remained valid and have never been substituted or replaced with other texts.

For this reason, the FC is not exempt from religious influence in Morocco, but rather King Mohammed VI has emerged as the sole interpreter of the Code (in his capacity as Commander of the Faithful), despite approval being submitted to Parliament. And, in so far as the King stands as supreme interpreter of its provisions, the authorities of the court order will have to follow his ijtihad.

The provisions of the Code are for personal application, of Moroccans (Muslims), regardless of whether or not they hold another nationality, whilst residing in Morocco but also overseas. Along these lines, although article 2 of the FC was not 


\section{G. ESTEBAN}

included in the old Moudawana its contents cannot be considered new, given that Morocco is a Muslim state and the aim of the FC is to regulate the homogenous relationships between Moroccan Muslims, be they refugees or stateless persons.

In the latter case, the extraterritorial application of its provisions means that the family relations of Moroccans are governed by the FC, even when they reside overseas, because all people who are believers or are faithful, are ruled by religious Law regardless of nationality. Nevertheless Moroccans of Jewish faith shall be governed by the provisions of the Hebraic Moroccan Family Law (article 2).

In the specific case of Morocco, regarding the interpretation of Islamic Law, the doctrine which prevails is that of the Maliki School which permeates at all times the sense of its provisions. From this perspective, it is important to consider that the revelations of the Prophet constituted a major change in the understanding of social relations, which is not, however, considered sufficient in our time for the defence of actual equality for women (equal opportunities) within the family and society.

The sentence of the Provincial Court of Jaén no. 175/2012, of 18th June (JUR 2013\139157), is a good example of the difficulties a correct application of the Moroccan FC can present to Spanish authorities. This case dealt with an issue relating to the capacity of a Moroccan woman married to a man of the same nationality to officially bind him to a loan agreement of industrial machinery to be used by a family business, signed by both spouses.

The lack of a correct understanding of article 51 of the FC prevents an adequate defence of the defendant. It was considered a question of wife's capacity, but, in fact, it was a problem of her consent to sign the loan (with his husband).

\section{Analysis of Spanish Jurisprudence}

\section{Marriage: The Dowry}

The celebration of marriage is a universal right (ius connubii). In Spain, article 32 of the Constitution protects this right, but at the same time, refers to the law that regulates it and, in turn, the law has left plenty of scope for people to choose the way of celebrating their marriage.

As is known, in Spain, the marriage system is unique, consisting of dual forms: civil and religious, and whose effects, regardless of the type of ceremony, will be the civil. The celebration of a marriage is configured as a solemn act, in which consent has to conform to certain formalities, and at which an authority figure must be present, giving rise to the relationship between the authority and the form (lex magistratus).

In general, under Muslim Law, a man must hand over a dowry to his wife as a symbol of his desire to enter into marriage with her, as foreseen in the current Moroccan Family Code. Article 13 of the FC states that: "The conditions required to contract marriage are: The legal capacity of both spouses to marry; No intention or agreement to cancel the dowry; A marital tutor (wali), if required; The hearing and notarized statement by two adouls (public notaries) of the offer and acceptance pronounced by the two spouses; The absence of any legal impediments". The dowry is fundamentally a requirement for a valid marriage celebration. Furthermore it plays an important role in cases of dissolution or if the husband dies, given that it is a debt to his wife.

That is, it offers economic security to the wife before such situations. The FC foresees that: "The dowry is that which the husband gives to his wife as an expression of his desire to marry her and to build a stable family based on affection and good amicable relations between husband and wife. Its legitimacy is based on its moral and symbolic value rather than its material value" (article 26).

The legislature makes clear that its value is symbolic, not material, so it cannot be regarded as a payment, rather as a notion that is the product of the historical circumstances of a specific time and at the same time, of both economic and social changes experienced by the present Moroccan society. Along with this, the legislature has gone further in stating, in article 27 of the FC, that: "The dowry amount is specified upon the conclusion of the marriage contract, and in the event it is not specified, the marriage is deemed one of entrustment". The wife is entitled to the full dowry after the consummation of the marriage or before that time if the husband dies before consummation has taken place (and also in cases of "marital privacy”).

If not delivered in full (if it is a sum of money), at the time of the celebration of marriage, it becomes a debt acquired by the man towards the woman which will eventually be inherited by his heirs. For this reason, the treatment of the dowry in such cases could be considered closer to the field of property law, and not family law, given that it is an actual debt which can be claimed in court.

The lack of correspondence at present of the dowry in Spanish legislation has led the courts, even those inclined to its recognition, to resolve inadequately those cases that have been raised by spouses united by marriage according to their personal law or in a mixed marriage, when one party holds either Moroccan nationality or that of another country where the dowry exists.

From the point of view of marriage in Spain, the requirements present could be considered a limitation inconsistent with the freedom to marry and contrary to the principle of equality and, therefore, a public policy issue. If a female Moroccan immigrant claims before the Spanish authorities the payment of her dowry, it would not make sense-as has happened previously - that her claim be dismissed simply because the dowry constitutes an institution which does not currently exist in Spanish legislation. This response is inconsistent with women's rights, given that she should be protected by a foreign legislation. In any case the relevant public policy must tread carefully.

The doctrine has made a series of proposals to determine the legal status of the dowry in Private International Law according to its function in each case: if it regards questions of alimony, the applicable law is the law governing alimony between spouses, if it operates as a pension paid on death of the husband, the applicable law should be the law governing the succession (article 9.8 of the Spanish Civil Code, CC from now on), and, finally, if the existence or non-payment of a dowry affect the validity or nullity of marriage in Spain, it would be inconsistent with public policy. This is what happened in the famous case resolved by Judgment no 5/2004 of the Provincial Court of Castellón (Section 3), January $21^{\text {st }}, 2004$, where an appeal was made (by a woman) against the verdict offered by the court. The interested parties were married in the Islamic way in the Embassy of the Republic of Iran in Spain. During the celebration the man promised the woman a dowry of 3000 euros.

Before the court's decision rejecting the claim for the payment of dowry, the appellant (an Iranian) was directed to the 
AP, who reiterated the arguments of the court: on the one hand, the marriage was not celebrated validly in Spain, nor was it registered in the Civil Registry. On the other, the dowry is considered an effect of marriage, regulated under article 9, 2 of the $\mathrm{CC}$ and therefore under Spanish law, which does not recognise the dowry at present. And finally, proof of the Law of the Republic of Iran (a requirement of the Spanish Supreme Court) was not provided.

In any case, a claim petition for payment of the dowry would not be covered by article 9.2 of the CC, as, according to the Moroccan FC, it shall not be considered an effect of marriage, but is rather a requirement for the valid celebration of the marriage, without which a marriage is invalid. On the other hand, if the dowry is considered through the application of article 9.3 of the $\mathrm{CC}$, that is as an aspect included in the property regime of the marriage, it would not correspond to its meaning in the Moroccan Law which states that its value is symbolic, and not economic or material.

For this reason it can be said that Private International Law does not yet hold the necessary instruments to respond to questions raised by the dowry, as regulated in the FC. From the perspective of the Spanish system of Private International Law the dowry should be considered a condition for the valid celebration of marriage, when celebrated on Spanish soil, in a legally recognized religious form, and, in particular, under Islamic faith. And in cases where a delegated marriage has been celebrated (as stipulated in the Moroccan FC), and the woman claims her dowry before the Spanish authorities, a possible classification of the case under the system of Private International Law is that of debt (financial).

\section{Dissolution of Marriage}

Is This Regulation Incompatible with Public Policy?

The regulation of the dissolution of marriage, according to the FC, maintains-largely-the religious comprehension of family and social life. This is the main reason why such changes have not had a decisive impact on the understanding of the function of the dissolution of marriage in Moroccan law. Talaq consists of a unilateral dissolution presented by one of the spouses, usually the husband, given that if the request is presented by the woman she must first seek her husband's consent (arts. 78, 79 and 89 FC), either because this right was handed over at the moment of celebration of the marriage ( $\left.t a^{\prime} l i k\right)$, in exchange for compensation $\left(j u l^{c}\right)$ or for the remainder of the dowry if it has not been paid in full.

Court authorization is required in any case. Article 79 of the FC states that: "Whoever wishes to repudiate must petition the court for authorization to certify the repudiation by two adouls (public notaries) accredited for this purpose in the judicial district of the conjugal domicile, the wife's domicile or place of residence, or the place where the marriage contract was issued, in that order". And article 115 refers specifically to mutual consent $\left(j u l^{C}\right)$, considered a form of divorce (article 72 FC). As declared by the Moroccan High Court, in Sentence of $13^{\text {th }}$ January 1998, this mode of dissolution is invalid if the woman is not present. In the stated case, the woman did not attend the act of $j u l^{c}$.

The court will also determine an amount to be paid in compensation to the woman ( $m u t^{c} a$ ) for damages caused by the dissolution of the marriage, assessed based on the length of the marriage, and the degree to which the husband has abused this right, etc. (art. 84 FC).
The Sentence of the Provincial Court of Barcelona 582/2010, 14th October, on the dissolution of a marriage between two Moroccans, considers the mut'a to be equivalent to the compensatory pension in Spain. On the other hand, the doctrine of the Constitutional Court is applicable, as in the well-known Sentence $10 / 2000$ of $17^{\text {th }}$ January, under which the court has to use all means at its disposal to bring the foreign law into the proceedings, when the actor has brought a minimum indication of proof of its content. The wife may petition for divorce $t a$ 'liq if one of the causes stipulated in article 98 of the FC occurs. These are: Non respect by the husband of one of the conditions in the marriage contract; harm; non-maintenance; absence; latent defect $(a y b)$ or abstinence and abandonment.

Divorce can also be declared through the courts on petition of the husband if there is reasonable doubt surrounding paternity of his son (article 159 FC). In these cases an imprecation of adultery takes place, during which the husband must swear five times, saying "I testify by Allah that I am truthful in charging her with adultery or that this foetus is not mine" four times and on the fifth "And may the curse of Allah be upon me if I am lying". If the woman denies the accusation, she must swear four times "I testify by Allah that he is lying about what he has charged me with". And the fifth time say "And may the wrath of Allah be upon me if he is telling the truth". The judge will honour the divorce as the oaths prove that trust has been lost between the spouses.

Alongside these the FC offers two new forms of dissolution of a marriage: by mutual consent (al-talaq b-l-ittifaq) as in article 114 of the FC, and for irreconcilable differences (taTliq li $a$-siqaq), under article 94 of the FC. Both the woman and the man can ask for these two forms of divorce before a judge.

The question arises whether the fact that the FC regulates the forms of dissolution of marriage which a man or a woman can apply for differently is, in itself, incompatible with Spanish (international) public policy. Firstly it is necessary to delimit the essential content of fundamental law, as it is not possible to apply or take into account foreign law, because these aspects are regulated by rules of necessary application.

For this reason the doctrine is critical of the use of the public policy of proximity, justified in the limitation of reactions available to public policy (against a foreign law), demanding a minimum link in the relationship with the forum (salamé). And consequently and assessment must be made of the point at which it is feasible to stop considering the essential content of fundamental law in order to give way to cultural diversity (legal), insofar as the norms of conflict require the application of a foreign law.

At present a new interpretation of public policy is called for, whose objective is to verify to what point fundamental law can be interpreted in accordance with the value of cultural diversity. This new interpretation would require consideration of public policy as being integrated by its more specific contents linked to comparative law rather than the more general human rights.

For this reason, the application of Moroccan Law cannot be omitted on the grounds that it is incompatible with Spanish public policy, as, if the essential content of the rights to equality are interpreted, and according to the (cultural) guidelines laid out in Islamic Law, it may be understood that the differences have been upheld (ounnir), and are present in the way dissolution of marriage is conceived.

So, public policy must act in a way which is not only attenuated but also limited, that is to say more as a clause than as an 
exception - as stated above. On the other hand, as stated by the doctrine (borrás), it is necessary to increase the adaptability of the action of the rules of application (of the rule of conflict) and, specifically, of the public policy, as this can no longer be interpreted in the sense that a foreign law must cease to be applied for the mere fact that it contradicts the basic principles of the forum legislation, given that this solution may be unjust from a material point of view in the current context of the formation of immigrant and multicultural societies.

The difference lies in the fact that a clause can be clarified, whilst the action of the exception takes place before circumstances which are assessed as public policy issues. According to the Savignian concept of public policy, this was the expedient necessary to impede in the forum the application of foreign laws not pertaining to occidental civilisations and, especially, in the historical context examined by this author, in the Ottoman Empire.

For this reason, the conflict between civilisations was latent in such a proposal and, from there, the function of public policy as an exception stems In any case, it is important to consider the notion of social integration as seen from the perspective of Private International Law, which requires that the connection which is established in the forum be recognised under the legislation of origin (recognition method).

The use of public policy as a safeguard clause allows consultation of the foreign Law and its application when this is not incompatible with the essential content of the fundamental law of the forum, as happens in this case, given that the current regulation foreseen in the FC relating to the dissolution of marriage is not incompatible with the right to equality. The fact that new ways of dissolution of a marriage have been introduced, allowing both parties to terminate their relationship through the same procedure and alleging the existence of disagreements must also be taken into account (article 97 FC).

Thus public policy becomes a safeguard clause, that is, a limit on the possibility of the forum accepting the cultural peculiarities or specifications of the foreign law, as this is not permitted by the sense in which this fundamental law is regulated, not only in the forum's legislation but also in the international community. The critique made of the ethnocentric character of human rights must also be considered. Finally, and in any case, even when the foreign law is not to be applied, its specifications can be considered in order to, for example, promote recognition of the decision in the country of origin of the immigrant.

That is, even when the public order clause has impeded the application of the foreign Law, there remains scope for the consideration of its specialities as a way to take responsibility for the free development of the personality and to promote the recognition of decisions in the home country of the person who migrates.

In this way intercultural communication between the legislations of the country of origin and of residence of the immigrant is favoured. Thus public policy acts more as a safeguard clause whose action is limited than as an exception and, in any case, it is subject to the "recognition method", as it is also important to verify-in order to make such a comparison-, whether the connection established in the forum will be recognised in the immigrant's home country.

The District Court ruling of Murcia, number 166/2003 (Section 1), 12th May, acts as an example of the action of public policy as an exception, where even the judicial authority went to the trouble of finding out the content of a foreign law (in this case the Moroccan law relating to the causes for the dissolution of marriage), to prove that the public policy had acted in haste [Court of Appeal no. 66/2003 (BDA, AC 2003\1676)]. However this procedure is justified only when public policy is seen as an exception which, insofar as the authority appreciates the incompatibility with the higher principles or values of the forum's legislation, cannot stop the exception being used to discard the application of a foreign law.

Nevertheless, public policy as a clause allows the content of a foreign law to enter, a comparison to be established with the regulation given by the forum's legislation, and an assessment made of its possible incompatibility with the higher principles or values. The doctrine mentions, along these lines, a specific public policy dedicated to the defence of fundamental laws (Hammje, 1997). To do this, the content of the foreign law must be consulted, compared with the considered fundamental law, and if it is not compatible with the superior values of Spanish law, it may not be applied.

The terms of this comparison are: the essential content of the fundamental law, which expresses the higher values of the forum's legislation, on one side, and on the other, the effect produced by the specific application of the foreign law in the forum. Now to another sector of the doctrine, public order does not act against the foreign law as a set of rules, but against a part of it, made up of concrete and specific rules that conflict with the principles or values of the forum (Mosconi, 1989).

\section{Legal Separation of Moroccan Women in Spain}

Other cases of special interest are those presented at a specific time period in Spain, where female Moroccan immigrants filed for divorce from their husbands, of the same nationality. These requests led to a series of differing responses, cumulating in the reform of article 107 of the CC, and the birth of Organic Law 11/2003 of 29th September (Official Gazette of Spain no. 234, 30th September). This modification was related to the situations of helplessness in which Moroccan women, victims of abuse, found themselves when, in order to maintain the order of protection, they were obliged to file a civil action in the home within 30 days, according to article 544 of the Criminal Procedures Act (after modification by Law 27/2003, 31st July) (Official Gazette of Spain no. 183, 1st August 2003).

At that time, the fact that the possibility of filing for divorce without prior judicial separation was not referred to in Spanish law thwarted these claims, causing a patently unfair result for Moroccan women. The dissolution of marriage was governed by article 107 of the CC, according to which Moroccan law would be enforced, as both interested parties held that nationality.

Nowadays, these situations do not occur, because divorce has become independent of legal separation under present Spanish legislation, so the Moroccan immigrant woman can divorce in accordance with the indications of the Spanish law, as provided in the current Regulation 1259/2010, of the Council of 20th December 2010, for which enhanced cooperation in the field of the law applicable to divorce and legal separation is established (article 5). This regulation became effective on 21st June 2012 (Official Journal of the European Union, Series L, no. 343, 29th December 2010).

\section{Revocable and Irrevocable Characteristics of the Dissolution of Marriage}

Another question which has caused suspicion to the Spanish 


\section{G. ESTEBAN}

authorities relates to the revocable nature of certain methods of marriage dissolution expressed in the FC. Specifically, there are both revocable and irrevocable methods of dissolution, but the revocable methods stated in the Code also become irrevocable over time. As a general rule, any divorce granted by the court is irrevocable, with the exception of cases of divorce on the grounds of abandonment and non-maintenance (article 122 FC).

Contrarily, any divorce pronounced by the husband (talaq) is revocable, with the exception of: a third repudiation (presented by the husband), divorce before the marriage is consummated,

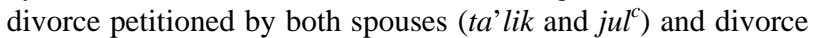
by mutual consent (article 123 FC). There are doubts surrounding the possibility to revoke this method of dissolution of a marriage as foreseen in article 114 of the FC, as it is not strictly a form of talaq, referred to in article 123.

If the husband wants to take back his wife after a revocable divorce, two adouls (public notaries) shall certify this and immediately inform the judge, and the wife's consent is also necessary [article 124 CF: "The husband may take his wife back during the legal waiting period (iddat). If the husband wants to take back his wife after a revocable divorce, two adouls (public notaries) shall certify this and immediately inform the judge. Before validating the 'resumption document', the judge must summon the wife to inform her of this. If she does not comply with this request and refuses to return, she may resort to the irreconcilable differences procedure in preceding Article 94"].

The length of time for which the dissolution of the marriage is revocable corresponds to the ${ }^{c}$ idda (legal period of continence), which is three menstrual months. However there are a number of exceptions, taking into account whether the woman is pregnant at the time of declaring repudiation or divorce, or whether the woman has regular or irregular menstrual cycles, or is in menopause. The objective of the long-winded regulation of these cases (article 136 FC) is to avoid any confusion in the affiliation, as Allah revealed to the Prophet.

When recognition by the Spanish authorities was called for of a Moroccan decision on the revocable dissolution of marriage, the General Directorate for Registries and Public Notaries (GDRPN) considered that there is no uncertainty about the circumstances of the marital status of the person and therefore it is incompatible with public policy. Of particular relevance is the Resolution of 26th October 2006, which denied the registration of a marriage, given that there was no record that previous matrimonial ties had been broken, which goes against public policy (Official Gazette of Spain 13th December 2006).

The case referred to a marriage registration dossier in which an appeal was brought against a decision issued by the Clerk in charge of the central Registry Office, rejecting the registration of a marriage celebrated in Morocco on $10^{\text {th }}$ September, 2000. The husband was born in Morocco in 1972 and held Spanish nationality, and his wife was born in Morocco in 1972, of Moroccan nationality. The husband was obliged to present the original marriage certificate and the marriage license, which states that he was divorced as of 7th October 1999, a divorce of revocable nature.

On 17th January 2005, the Clerk of the Registry Office passed sentence denying registration of the marriage, as previous matrimonial ties still existed. The divorce was not considered to be an authentic dissolution of marriage as its revocable nature meant that the ties had not been definitively broken. For its part, the GDRPN considers the "application" of Moroccan law is incompatible with the public policy of the forum, be- cause it does not provide assurance of the marital status of a person.

Specifically, the GDRPN considers that although the Moroccan legislation accepts the second marriage as valid, the foreign law on personal status cannot be applied as: “... the foreign law, applicable as a rule according to our norms of conflict, must be excluded in this case by virtue of its conflict with international public policy (article 12.3 CC), which does not allow registration of a possibly polygamous marriage as this infringes on the Spanish concept of marriage and the constitutional dignity of the woman, ... in the same way that it is forbidden during registration in the Spanish registry office to record the fact that one of the spouses was already married at the time the marriage was celebrated, neither can the fact that the divorce from a previous marriage is of revocable nature be recorded, as dissolution of the marriage by divorce may only take place by means of judgement declaring the divorce, effective once the judgement becomes final (article 89 CC).... the marital status of both parties in this moment is a requisite in the registration of the marriage".

However, in this case public policy should not prevent the Moroccan decision of dissolution being recognised and, thus, registration of the new marriage should take place, paying attention to the regulation in the legislation of the revocable nature of the termination of matrimonial ties (see above). The position of the GDRPN cannot be accepted for various reasons: firstly, for the fact that it contemplates recognition of a Moroccan decision on the dissolution of marriage and, more specifically, the issue of the termination of the personal bond of marriage.

It is not a question of recognising the possibility of a person, having terminated his marriage, resuming co-habitation with his first spouse, if he so desires, as they are, to all intents and purposes, still married. In this case, if both parties wished to resume said co-habitation, it would be necessary to celebrate a new marriage. Therefore, the issue presented before the GDRPN is not related to the application of Moroccan Law, rather to whether or not decisions made in Morocco on the dissolution of marriage are allowed to take effect before the forum.

Even if this issue had been raised from the perspective of the application of Moroccan law by the Spanish authority, it cannot be considered to be inconsistent with public policy, as the fact that the foreign law governs the termination of the personal bond of marriage can be accepted, without taking into consideration its revocable nature. That is, if reconciliation occurs, a couple will be required to remarry.

Consider, on the other hand, the similarities between the revocable nature of the dissolution of marriage and the status of legal separation. These similarities mean that the FC cannot be considered incompatible with the international public policy of the forum. In short, if the public policy mentioned acts as a clause, the foreign law may be consulted, in the first instance. Secondly, it allows for a comparison with the regulation offered by Spanish legislation and, finally, there is room to assess its possible compatibility with the superior values of the forum.

\section{Conclusion}

The legal-family situation of female Moroccan immigrants in Spain cannot be treated mechanically; rather, cultural aspects must also be taken into consideration. To this end, the solutions 
offered under Private International Law linked to immigration must respect "cultural identity" and also "cultural diversity" common to these private relationships. Furthermore the Spanish system of Private International Law must promote the continuity of the family relations of people who migrate in their foreign place of origin.

Finally, as part of the gradual formation of multicultural societies, the understanding of the role of public policy is changing, to the extent that it acts once the content of the foreign law is apparent (an action in advance of public policy cannot be considered), dismissing application of the law if it is contrary to the higher values of the forum, and provided that it cannot be interpreted taking into account the foreign cultural specificity (legal).

\section{REFERENCES}

Adam, Mª D. (2004). La modificación del artículo 107 del Código civil y su incidencia en cuanto a la protección del derecho a la no discriminación por razón de sexo, Ámbitos. Revista de Estudios de Ciencias Sociales y Humanidades, $2^{\mathrm{a}}$ época, núm. 11, 79-92.

ADJJ (2005). Guide pratique du Code de la famille. Rabat: Ministerio de Justicia.

Aguilar, M. (2005). Los problemas de aplicación de la norma de conflicto: Una concepción internacionalista y funcional. In AAVV. Pacis Artes. Obra homenaje al Profesor Julio D. González Campos (pp. 1133-1150). Tomo II. Madrid: EUROLEX

Borrás, A. (1988). Europa multicultural. El caso de España. In A. Borrás, \& S. Mernissi (Eds.), El Islam Jurídico y Europa. Derecho, Religión y Política (pp. 159-173). Barcelona: Institut Català de la Mediterrània.

Botiveau, B. (1993). Loi islamique et droit dans les sociétés arabes. París: Karthala.

Cervilla, Ma D., \& Zurita, I. (2010). El Derecho de familia marroquí. La Mudawana 2004 desde el Derecho español. Madrid: Difusión Jurídica.

Deprez, J. (1977). La reforme de l'organisation judiciaire et de la procédure au Maroc (Dahirs des 15 juillet et 26 septembre 1974) et le Droit international privé. Revue juridique, Politique et Economique du Maroc, 3, 45-56.

Deprez, J. (1978). La reforme de l'organisation judiciaire et de la procédure au Maroc (Dahirs des 15 juillet et 26 septembre 1974) et le Droit international privé (deuxième partie). Revue Juridique, Politique et Economique du Maroc, 4, 49-60.

Deprez, J. (1981). Bilan de vingt-cinq années de droit international privé au Maroc. Revue juridique, politique et économique du Maroc, $10,125-151$.

Diago, M ${ }^{\mathrm{a}}$ P. (2001). La dot islamique à l'épreuve du conflit des civilisations sous l'angle du Droit international privé espagnol. Annales de Droit de Louvain, 4, 407-420.

Esteban, G. (2009). Inmigración y Derecho internacional privado. Madrid: Difusión Jurídica.

Esteban, G. (2011). La integración social de los inmigrantes desde la perspectiva del sistema (español) de Derecho internacional privado. In J. Gavidia Sánchez (Ed.). Inmigración, Familia y Derecho (pp.155-179). Madrid: Marcial Pons

Esteban, G. (dir.) (2009). La nueva Mudawwana marroquí (entre tradición y modernidad). Traducción anotada del Código de Familia de Marruecos. Sevilla: Consejería de Gobernación, Junta de Andalucía.

Esteban, G., Ouald, K., \& Saghir, T. (2007). Comentario a la Sentencia de la AP de Barcelona, núm. 381/2006 (Sección 12ª), de 8 de junio, Revista Española de Derecho Internacional, I, 304-307.

Fargues, Ph. (1996). La demografía de la familia en el Magreb: una clave para la comprensión de la familia. In $\mathrm{M}^{\mathrm{a}} \mathrm{A}$. Roque (Ed.), Las Culturas del Magreb (pp. 137-149). Barcelona: Icaria.

Feldstein, S. L. (2003). El orden público internacional: Una mirada desde el Derecho internacional privado contemporáneo. In A. L.
Calvo Caravaca, \& P. Blanco-Morales Limones (Eds.), Globalización y Derecho (pp. 266-275). Madrid: Colex.

Foblets, $\mathrm{M}^{\mathrm{O}}$-C., \& Carlier J.-Y. (2005). Le Code marocain de la famille. Incidentes au regard du droit international privé en Europe. Bruxelles: Bruylant.

Foblets, Ma-C., \& Loukili, M. (2006). Mariage et divorce dans le nouveau Code marocain de la famille: Quelles implications pour les Marocains en Europe? Revue Critique de Droit International Privé, 521-543.

Gannagé, L. (2006). Le relativisme de droits de l'homme dans l'espace méditerranéen. Regards du proche-Orient sur la reconnaissance en France des répudiations de droit musulman. Revue International de Droit Comparé, 58, 101-1116.

Gaudemet-Tallon, H. (2005). Cours général. Le pluralisme en droit international privé: Richesses et faiblesses (le funambule et l'arcen-ciel). Recueil des Cours, 312, 275-315.

Gavidia, J. (2012). Inexistencia, nulidad del matrimonio y sistema matrimonial (1st ed.). Barcelona: Bosch.

Gurvitch, G. (2005). La idea del Derecho social. Granada: Comares.

Hammje, P. (1997). Droits fondamentaux et ordre public. Revue Critique de Droit international privé, 1-35.

Kreuzer, K. (2008). International Instruments on Human Rights and Shariah Law. In Vers de nouveaux équilibres entre ordres juridiques. Mélanges en l'honneur de Hélème Gaudemet-Tallon (pp. 343-356). París: Dalloz.

Loukili, M. (2010). El reconocimiento de decisiones en Marruecos en el ámbito del Derecho de familia. In Inmigración e integración de los inmigrantes desde una perspectiva hispano-francesa en el contexto de las actuales políticas comunitarias sobre inmigración (285-304). Granada: Comares.

Mayer, D. (1977) Evolution du statut de la famille en droit international privé. Journal du Droit International, 453-465.

Miaja, A. (1953). La teoría del desdoblamiento funcional en el derecho internacional privado. Revista Española de Derecho Internacional, 145-163.

Mosconi, F. (1989). Exception to the operation of choice of law rules, Recueil des Cours, 217, 143-200.

Muir Watt, H. (2001). Le modèles familiaux á l'épreuve de la mondialisation (aspects de Droit international privé). In A. L. Calvo Caravaca, \& J. L. Iriarte Ángel (Eds.), Mundialización y familia (pp. 11-24). Madrid: Colex.

Ouald, K. (2001). La regulación de la disolución del matrimonio en el Derecho marroquí. In J. Gavidia Sánchez (Ed.), Inmigración, familia y Derecho (pp. 289-314). Madrid: Marcial Pons.

Ouhida, J. (2009). Del Código del Estatuto personal y de las sucesiones al actual Código de familia de Marruecos de 2004. In G. Esteban de la Rosa (Ed.), Traducción del Código de familia de Marruecos (pp. 17-42). Jaén: Imprenta Blanca.

Ounnir, A. (2008). La reconnaissance et l'exécution des jugements étrangers au Maroc. Estudios e Informes sobre la Inmigración extranjera en la provincia de Jaén (2005-2006), Observatorio Permanente sobre la Inmigración en la provincia de Jaén, Comares, Granada, 451-465.

Ourkia, A. (2012). Las fuentes del Derecho malikí y su influencia sobre el Código de Familia de Marruecos. In G. Esteban de la Rosa, \& J. A. Menor Toribio (Eds.), Estudios e Informes sobre la inmigración extranjera en la provincia de Jaén (2009-2011) (pp. 340-352). Comares: Granada.

Pérez-Agote, A. (2005). En la era global: ruptura de ecuaciones y dicotomías de la modernidad. In A. Ariño Villarroya (Ed.), Las encrucijadas de la diversidad cultural (pp. 313-340). Madrid: CIS.

Quiñones, A. (1999). El estatuto personal de los inmigrantes musulmanes en Europa: Exclusión, alternancia y coordinación de sistemas. In XVII Jornadas de Profesores de Derecho internacional y Relaciones internacionales (pp. 181-193). Madrid: BOE.

Quiñones, A. (2004). Ressortissants des pays islamiques résidant en Europe: quel droit de famille? In Migration et citoyenneté, Actes $d u$ Colloque international organisé á la Faculté de Sciences juridiques, economiques et sociales Rabat-Agdal (pp. 158-170). Rabat: AMERM.

Remy, B. (2008). Excepción d'ordre public et mécanisme des lois de 


\section{G. ESTEBAN}

police en Droit internationale privé. París: Dalloz.

Rodríguez, A. (2011). El Estatuto personal de los extranjeros procedentes de países musulmanes. In: Derecho islámico e interculturalidad (pp. 90-110). Madrid: Iustel.

Ruiz-Almodóvar, C. (2005). El derecho privado en los países árabes: Códigos de estatuto personal. Granada: Universidad de Granada y Fundación Euroárabe de Altos Estudios.

Salamé, G. (2006). Le devenir de la famille en Droit international privé.
Aix-Marseiille: PUAM.

Vischer, F. (1976). Der Wandel im Familienrecht und das internationale Privatrecht. In Familienrecht im Wandel. Festschrift für Hans Hinderling (pp. 320-354). Basel and Sttutgart: Helbing and Lichtenhahn Verlag.

Zeghal, M. (2006). Islam e islamismo en Marruecos. Barcelona: Bellaterra. 